\title{
Conceptual change of disaster management models: A thematic analysis
}

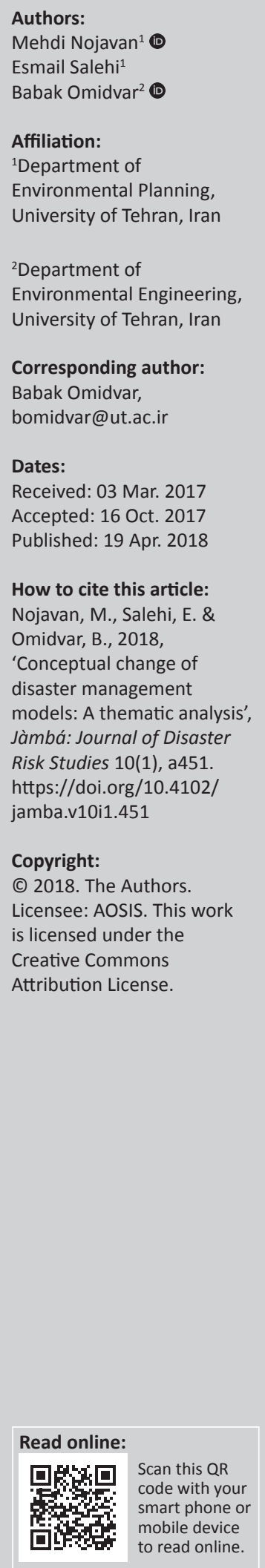

Different models have been proposed for disaster management by researchers and agencies. Despite their efficiency in some locations, disasters are still a fundamental challenge in the way of sustainable development. The purpose of this research is developing a comprehensive conceptual model for disaster management using thematic analysis. In this regard, first, disaster management models are collected. In the next stage, the themes of each model are extracted and categorised in three phases. In the first phase that is descriptive coding, available elements in each model are extracted as code and the basic themes are recognised. Then, in the phase of interpretive coding, basic themes are classified in three categories that are called organising themes (i.e. hazard assessment, risk management and management actions). In the final phase, strategic management is selected as the global or overarching theme to integrate all the other themes. Based on thematic analysis, it can be concluded that disaster management has three main elements that are the three organising themes. Therefore, comprehensive model of disaster management should include these three elements and their sub-basic themes that is called the ideal or criterion type. Results showed that some scientists have looked at disaster management one dimensionally (one theme). Even in two-dimensional models, one dimension has advantage over the other one. While the proposed typology in this study showed that the comprehensive model should include all the three mentioned elements.

\section{Introduction}

One of the environmental difficulties and problems that the world's biggest human settlements are facing is the problem of disasters. In recent decades, a striking world-wide trend towards rising fatalities and economic losses because of natural and man-made hazards can be seen all over the world. One of the important and influencing factors for this increment is growing urbanisation, and most importantly, the settlements that are particularly prone to supply crisis, social disorganisation, political unrest, natural and man-made disasters because of the high population density and extreme dynamics of development (Kraas 2008). Considering that countries all over the world are increasingly urbanising (Dutta 2012), according to the United Nations forecast, it is expected that almost $80 \%$ of the world will live in cities by 2050 (Jha, Miner \& Geddes 2012). This means that urban areas will turn into the main location for many potential disasters (León \& March 2014). Therefore, planning for disasters in urban areas should be considered as the main and basic strategy in all phases of urban planning.

Disaster management is considered as one of the main factors affecting disaster prevention and an effective strategy when they happen. However, despite the fact that disasters have always been along with humans, disaster management is still a relatively new profession and scientific field (Asgary 2006). As a new profession and scientific field, disaster management also needs to develop its principles and foundation to be able to continue as a professional and scientific field. In line with that, researchers and experts have always been trying to find principles for this field and profession. Kelly (1998) defined four main reasons for the necessity of developing a (theoretical) model for natural disasters management. He stated that a model can simplify complex events by helping to distinguish between critical elements.

In this regard, different models have been proposed for disaster management by researchers and agencies. Quarantelli (1994) attempted to develop the principles of disaster management. To him, 'principles of good and efficient disaster planning' have certain characteristics that can be used as general principles. Cuny (1998) defined a cycle for disaster management, which is one of the most complete cycles in which the managerial and executive measures and activities to be taken during a disaster have been considered. Mileti (1999) developed a set of principles for preventing and reducing the negative effects of natural disasters. Kimberly (2003) proposed a 
four-phase model of disaster management. In this model, special attention has been paid to emergency management. McEntire, Crocker and Peters (2010) proposed an integrated approach for modelling vulnerability based on physical science, engineering, structural and organisational schools. Organisational school, which is the most recent school in natural hazards, has been formed based on the concept of resiliency. Van der Waldt (2013) also proposed steps towards a unifying theory as overarching paradigm for disaster risk management.

However, the process of forming different models has been criticised step-step throughout history and new approaches have been formed and each of them has been criticised, considering the historic events. Alexander (1997) believes that approaches and models of disaster management and planning have not had any significant progress based on the following factors: death tolls have not fallen dramatically in response to improved mitigation, large-scale transfer of technology has not occurred and disaster relief has not been adequately combined with mitigation and economic development. Alexander (2016) also reviewed the modernday challenges facing researchers, scholars and practitioners who work in the field of disaster risk reduction. He stated that there is a need for a major revision in the body of disaster theory so that it can take into account dynamic changes in the modern world. On the other hand, disaster theory must adapt to new conditions if it is to remain the 'road map' that clarifies complex realities and enables disasters to be managed. Asghar, Alahakoon and Churilov (2006) argue that suggested models and approaches so far have some limitations. For example, design of most of the models revolves around the four main phases of disaster management: prevention, mitigation, response and recovery. In other words, these models are not designed to cover all aspects of disaster management, such as hazard assessment, risk management and their sub-components. Also, there is no model or approach that can encapsulate main and major activities of disaster management within a framework.

According to Contreras (2016), a number of indices have been developed for measuring vulnerability to disasters, but little attention has been paid to recovery indices. In other research, Bendito and Barrios (2016) discussed that developing a trans-disciplinary strategy that effectively integrates disciplines, approaches and knowledge systems will lead to greater and more sustainable impacts, together with more efficient use of financial resources.

Finally, Scott et al. (2016) developed a unique monitoring and evaluating framework for use by disaster risk management programmes to track the outcomes of their interventions and ultimately raise standards in this area. In that study, they discussed and noted a weakness in relation to monitoring and evaluating of disaster risk management and highlighted that disaster risk management capacity development programmes typically need help to develop and implement robust monitoring and evaluating systems.
Briefly, a review over the literature of previous theories reveals a big gap in disaster management approaches, for designing and establishing efficient models to confront extensive and extreme disasters (Mohapatra 2009). Different researchers have considered disaster management as a multistage process. So, each model has been designed for a specific need in the field of disaster management and there have been no comprehensive research about the structure of these models, typology and classification before.

Considering the weaknesses of the previous models, despite their efficiency in some locations and under certain circumstances, disasters are still a fundamental challenge in the way of sustainable development. Therefore, disaster management requires an arranged and regular system with an appropriate approach and model so that it can largely reduce the possibility of crisis negative consequences.

The primary aim of this research is to assess the current models of disaster management through thematic analysis. The secondary aim of the article is to classify and recognise organising themes of disaster management. The third aim of this study is to present a typology and a comprehensive conceptual model for disaster management.

Through thematic analysis as research method, this article will analyse the content of disaster management models to ascertain the basic and organising themes of models in order to develop a comprehensive model. It should be noted that this analysis pertains to models that have been proposed in various countries.

\section{Research methodology}

In order to develop a conceptual model for disaster management that can be used at different levels, combination of thematic analysis, classification and typology is used to overcome the conceptual complications and inconsistencies that exist among the models at first sight and to simplify development of the final model.

Thematic analysis is the approach of data analysis and reduction that is used to segment, categorise, summarise and reconstruct the qualitative data (Given 2008; Mills, Durepos \& Wiebe 2010). Classification is also very essential and plays a fundamental role in social sciences. In the simplest form, classification means regular arranging of entities in groups or categories, based on their similarities to each other. In statistical sciences, the goal of classification is generally to minimise intra-group variances and maximise inter-group variances (Bailey 1994).

Typology is the complicated and progressive system of saving and recovering information that provides regulating, comparing and classifying different instances of the study subject without any kind of loss in content value and diversity between types (Rich 1992). Typologies are generally conceptual and are one of the most famous theory templates (Doty \& Glick 1994). Although typology is a mental and 


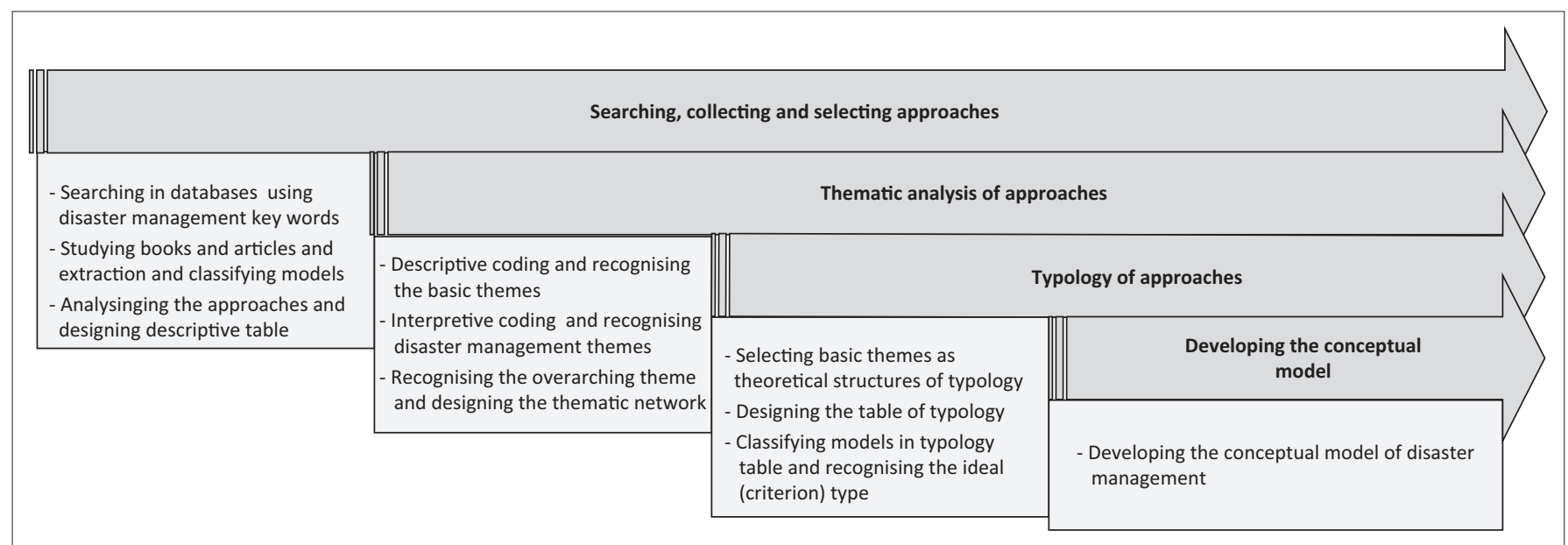

FIGURE 1: Research process in order to reach a conceptual model of disaster management.

innovative process which has no certain approach, Bailey (1994) has designed an approach for typology. In this approach, a full typology can be created based on ideal sample features. This process, which is based on expansion of the ideal type, is called proliferation. In this process, we achieve another set of types using multiplication of dimensions and features of the ideal type and choosing different combinations of them, which is called intermediate or middle types.

Based on the above-mentioned approaches, the first step of this study is to collect disaster management models, which is performed by the library studies and searching of various databases. In the second step of the study, thematic analysis is used for analysing the models. Besides offering the thematic network that has an overarching and almost comprehensive picture of the main elements of disaster management, this stage is a beginning to typology and model classification.

The third step is typology. After analysing the models, basic themes are recognised and are used as theoretical structure to form the types table. By multiplying the theoretical structures by each other and recognising their different combinations, all the possible types are created and named. Then, the models are classified by comparison and adjusting the models to types.

The final step of the study is developing a comprehensive conceptual model for disaster management that is proposed after the analytical discussion on different models and based on the ideal type. Indeed, the distinguished ideal type will be the theoretical credit for researchers' proposed model. Figure 1 shows the process of research in order to achieve a conceptual model for disaster management.

\section{Thematic analysis of disaster management models}

To find disaster management models, a search based on different combinations of a variety of keywords such as 'disaster', 'disaster management', 'disaster management models', 'disaster management cycle', 'emergency management', 'emergency operations plan', 'disaster management structure', 'emergency management organisation' and 'crisis management' was conducted. A comprehensive literature review of the World Wide Web was performed considering disaster management models. The search was performed in scientific and non-scientific databases because of the nature of research goals. The Web was searched mainly through Google, Bing, Yahoo and Ask search engines. On the other hand, Google Scholar was the main scientific database for investigating scientific materials. A large number of models have been presented by various researchers in this field, most of them for a specific disaster and place. In the first step, more than 100 models were collected in the field of disaster and crisis planning and management. So, after collecting all models, initial analysis was performed and the models that were not general models were excluded from the process of research. By the term 'general models', we mean the proposed models in the methodology articles that were written in the conceptual framework of the integrated disaster risk management in the managerial context. Technical notes, case studies, review papers and the other documents which emphasised the technological aspects of the risk analysis were excluded from the database.

Then, considering the main purpose of the study, 38 disaster and crisis planning and management models proposed by different researchers from 1941 to 2016 in different countries were selected for analysis. These models included general models.

Most articles and existing and available documents were studied and there were no comprehensive collection of these models in any book or article. However, Asghar, Alahakoon and Churilov (2006) have categorised disaster management models in four groups. But some of the models that are proposed by combination of different approaches and models are not fitted in any of the proposed groups. Therefore, in this study, another group called combinatorial models is suggested. This group points to a combination of logical, integrated and cause models (Table 1). 
TABLE 1: Description of disaster management models.

\begin{tabular}{|c|c|c|c|c|}
\hline $\begin{array}{l}\text { Classification } \\
\text { of models }\end{array}$ & Model title & Modeller (reference) & Abbreviated title & Explanations \\
\hline \multirow[t]{12}{*}{ Logical models } & $\begin{array}{l}\text { Traditional model: } \\
\text { sequences of action }\end{array}$ & DPLG-2 (1998) & $\begin{array}{l}\text { Traditional model (cycle } \\
\text { of disaster management) }\end{array}$ & $\begin{array}{l}\text { The different disaster management phases, rather than in a sequential manner, } \\
\text { run parallel to each other, albeit with varying degrees of emphasis. }\end{array}$ \\
\hline & $\begin{array}{l}\text { Expand and contract } \\
\text { model }\end{array}$ & DPLG-2 (1998) & $\begin{array}{l}\text { Expand and contract } \\
\text { model }\end{array}$ & $\begin{array}{l}\text { The difference with the traditional model is also often observed that the } \\
\text { sequences of action occur simultaneously. }\end{array}$ \\
\hline & $\begin{array}{l}\text { The four phases model } \\
\text { of disaster management }\end{array}$ & Kimberly (2003) & Kimberly model & $\begin{array}{l}\text { This model emphasises emergency management. The most important phase of } \\
\text { this model is the response phase. }\end{array}$ \\
\hline & $\begin{array}{l}\text { The four-stage model } \\
\text { of Tuscaloosa }\end{array}$ & Tuscaloosa (2003) & Tuscaloosa model & This model starts and ends with the response stage. \\
\hline & Circular model of disaster & Kelly (1998) & Kelly model & The main feature of this model is its ability to learn from real disasters. \\
\hline & Lechat model & Lechat (1990) & Lechat model & This model starts with anticipation of disaster and ends at the rehabilitation stage. \\
\hline & $\begin{array}{l}\text { The five-stage model of } \\
\text { Mitroff and Pearson }\end{array}$ & $\begin{array}{l}\text { Mitroff and Pearson } \\
\text { (1993) }\end{array}$ & $\begin{array}{l}\text { Mitroff and Pearson } \\
\text { model }\end{array}$ & This model emphasises the detection and learning phases. \\
\hline & Gupta stair model & Gupta (2010) & Gupta model & This model does not pay much attention to pre-disaster phases. \\
\hline & Mitroff model & Mitroff (2000) & Mitroff model & This model is a proactive model that emphasises the learning stage. \\
\hline & $\begin{array}{l}\text { Two-part model of } \\
\text { disaster management }\end{array}$ & $\begin{array}{l}\text { Hosseini and Jedi } \\
\text { (2006) }\end{array}$ & Two-part model & $\begin{array}{l}\text { This model includes a series of operational and logistic measures. So, this model } \\
\text { is called a two-part model. }\end{array}$ \\
\hline & Iceberg model & Heinreich (1941) & Iceberg model & $\begin{array}{l}\text { The main feature of this model is its attention to the structure and showing } \\
\text { seeming template of model. }\end{array}$ \\
\hline & Contreras model & Contreras (2016) & Contreras model & $\begin{array}{l}\text { In this model, a number of indices have been developed for measuring } \\
\text { vulnerability to disasters. The main feature of this model is its attention to the } \\
\text { reconstruction after disaster. }\end{array}$ \\
\hline \multirow[t]{6}{*}{$\begin{array}{l}\text { Integrated } \\
\text { models }\end{array}$} & Manitoba model & $\begin{array}{l}\text { Manitoba } \\
\text { Health Disaster } \\
\text { Management (2002) }\end{array}$ & Manitoba model & $\begin{array}{l}\text { Advantage and feature of this model is establishing a balance between preparation } \\
\text { and resilience, in order to respond to the specific needs of the disaster. }\end{array}$ \\
\hline & McConkey linear model & McConkey (1987) & McConkey model & McConkey model pays special attention to pre-disaster management in four stages. \\
\hline & $\begin{array}{l}\text { Weichselgartner } \\
\text { integrated model }\end{array}$ & $\begin{array}{l}\text { Weichselgartner } \\
\text { (2001) }\end{array}$ & Weichselgartner model & $\begin{array}{l}\text { The overall objectives of this model are the assessment of probable damage and } \\
\text { the planning of future measures to reduce this damage. }\end{array}$ \\
\hline & $\begin{array}{l}\text { Integrated model of } \\
\text { Moe and Pathranarakul }\end{array}$ & $\begin{array}{l}\text { Moe and } \\
\text { Pathranarakul (2006) }\end{array}$ & $\begin{array}{l}\text { Moe and Pathranarakul } \\
\text { model }\end{array}$ & $\begin{array}{l}\text { The results of this model show the importance of proactive and reactive } \\
\text { strategies in natural disasters management. }\end{array}$ \\
\hline & $\begin{array}{l}\text { McEntire et al. integrated } \\
\text { model }\end{array}$ & McEntire et al. (2010) & McEntire et al. model & $\begin{array}{l}\text { An integrated approach for modelling the vulnerability should consider social } \\
\text { science research, engineering and physics simultaneously. }\end{array}$ \\
\hline & Onion model & $\begin{array}{l}\text { Mitroff, Shrivastava } \\
\text { and Udwadia (1978) }\end{array}$ & Onion model & This model provides a framework for preparing organisations in the crisis. \\
\hline
\end{tabular}

Deming cycle model Aguayo (1991) PDCA model

Integrated system- Meshkati and

Monitoring and evaluating model of disaster risk management

\begin{tabular}{|c|c|c|}
\hline \multirow[t]{4}{*}{ Cause models } & Crunch cause model & $\begin{array}{l}\text { Asian Disaster } \\
\text { Preparedness Centre } \\
\text { (2000) }\end{array}$ \\
\hline & $\begin{array}{l}\text { Pressure and release } \\
\text { (PAR) model }\end{array}$ & $\begin{array}{l}\text { Blaikie, Mainka and } \\
\text { McNeely (2005) }\end{array}$ \\
\hline & $\begin{array}{l}\text { Fink's comprehensive } \\
\text { audit model }\end{array}$ & Fink (1986) \\
\hline & Littlejohn six-stage model & Littlejohn (1983) \\
\hline \multirow[t]{5}{*}{$\begin{array}{l}\text { Combinatorial } \\
\text { models }\end{array}$} & $\begin{array}{l}\text { Risk management } \\
\text { proactive model }\end{array}$ & $\begin{array}{l}\text { Australian } \\
\text { Development } \\
\text { Gateway (2008) }\end{array}$ \\
\hline & $\begin{array}{l}\text { Disaster risk } \\
\text { management framework } \\
\text { (DRMF) model }\end{array}$ & Baas et al. (2008) \\
\hline & Risk management model & $\begin{array}{l}\text { BPDMP (2013); } \\
\text { Zimmermann and } \\
\text { Stössel (2011) }\end{array}$ \\
\hline & $\begin{array}{l}\text { Wheel-shape disaster } \\
\text { management model }\end{array}$ & $\begin{array}{l}\text { Rowshandel } \\
\text { Arbatani, Purezzat } \\
\text { and Qolipoor (2008) }\end{array}$ \\
\hline & $\begin{array}{l}\text { Cuny comprehensive } \\
\text { model }\end{array}$ & Cuny (1998) \\
\hline
\end{tabular}

\begin{tabular}{|c|c|c|c|}
\hline & Saldana-Zorrilla model & $\begin{array}{l}\text { Saldana-Zorrilla } \\
\text { (2015) }\end{array}$ & Saldana-Zorrilla model \\
\hline & $\begin{array}{l}\text { Institutional model for } \\
\text { collaborative disaster risk } \\
\text { management }\end{array}$ & $\begin{array}{l}\text { Tau, Niekerk and } \\
\text { Becker (2016) }\end{array}$ & $\begin{array}{l}\text { Institutional model for } \\
\text { collaborative disaster risk } \\
\text { management }\end{array}$ \\
\hline \multirow[t]{2}{*}{ Other models } & Ibrahim et al. model & $\begin{array}{l}\text { Ibrahim et al. } \\
\text { (2003a); Shaluf et al. } \\
\text { (2003) }\end{array}$ & Ibrahim et al. model \\
\hline & $\begin{array}{l}\text { Gonzalez, Herrero and } \\
\text { Pratt model }\end{array}$ & $\begin{array}{l}\text { González, Herrero } \\
\text { and Pratt (1996) }\end{array}$ & $\begin{array}{l}\text { González, Herrero and } \\
\text { Pratt model }\end{array}$ \\
\hline
\end{tabular}

Integrated systemoriented mode

Monitoring and evaluating model of disaster risk management

Crunch model

PAR model

Fink's comprehensive audit model Littlejohn model

Australian Development Gateway model

Baas et al. model

Zimmermann and Kull model

Wheel-shape mode

The PDCA cycle with the continuous improvement cycle of plan, do, check and act was advocated after the Second World War.

The main feature of this model is its attention to the emergency response.

This model is a unique framework for monitoring and assessment of disaster risk management plans for use by disaster risk management programmes to track the outcomes of their interventions and ultimately raise standards in this area.

This model is a causal model that provides a framework for understanding the causes of the disaster; its structure is formed by the following equation: Disaster Risk = Hazard *Vulnerability.

Unlike the Crunch model and using preventive measures, try to reduce the disaster risk.

This model determines what events could cause a crisis in each functional area. Once scenarios are developed, action plans should be prepared.

This model is a framework that provides basic directives for disaster management. This model tries to combine logical and integrated model.

This model has the following three steps:

Risk reduction (Normal)

Emergency response

- Recovery.

The objective of this model is increment of community resilience and risk reduction using combination of logical and integrated models.

One of the comprehensive disaster management models is the wheel-shape model that is based on the life cycle of disaster and crisis, as well as its various stages. Also, it is formed by combination of logical and integrated models.

Cuny proposed a cycle for disaster management that is one of the complete cycles. This model considers administrative and management measures that are necessary in disaster management using a combination of logical, integrated and cause models.

This model provides a set of policy suggestions for integrating risk management and increasing risk reduction measures and planning.

This model combines the theoretical, political and technical dimensions of collaboration to enhance buy-in for the disaster risk management and reduction function of governments.

This model represents the technological disaster pre-condition stages.

This model states that with the pre-disaster measures, we can change the consequences of the crisis. 
TABLE 1 (Continues...): Description of disaster management models.

\begin{tabular}{|c|c|c|c|c|}
\hline $\begin{array}{l}\text { Classification } \\
\text { of models }\end{array}$ & Model title & Modeller (reference) & Abbreviated title & Explanations \\
\hline & Fink model & $\begin{array}{l}\text { Fink (1986); Penrose } \\
(2000)\end{array}$ & Fink model & This model includes prevention components and crisis analysis. \\
\hline & Statoil model & Statoil (2013) & Statoil model & $\begin{array}{l}\text { This model is a reactive model because it starts the activities after the } \\
\text { occurrence of disaster and lasts until returning the condition to the pre-disaster } \\
\text { normal condition. }\end{array}$ \\
\hline & Pagoda model & Okada (2004) & Pagoda model & City has been considered as a vital five-stage system in this model. \\
\hline & Octopus model & Shi et al. (2011) & Octopus model & $\begin{array}{l}\text { As disasters have complex systems, mutual risk management should be based } \\
\text { on multidimensional system for achieving success from policy-making viewpoint. } \\
\text { This model is proposed based on this viewpoint. }\end{array}$ \\
\hline
\end{tabular}

PAR, Pressure and release; DRMF, Disaster risk management framework; DPLG, Department of Provincial and Local Government; BPDMP, Badakhshan Provincial Disaster Management Plan; PDCA, Plan Do Check Act.

The first category is logical models. Logical models provide a simple definition of disaster stages and emphasise the basic events and actions that constitute a disaster. Traditional model of disaster management is one of the well-known and common logical models. In this model, the traditional process of disaster management has three phases: before, during and after the disaster. The first phase consists of activities such as prevention, mitigation and preparedness, while the second phase includes activities connected to reaction and response and the third phase includes activities such as recovery, reconstruction and development (ADPC 2000).

The second category of models are integrated models. An integrated model of disaster management is a tool for organising the involved activities in order to ensure effective and efficient implementation, and four factors can be identified for it: hazard assessment, risk management, mitigation and preparedness.

The Manitoba model is one of the famous integrated models. This model generally consists of six independent elements, namely strategic plan, hazard assessment, risk management, mitigation, preparedness, and monitoring and evaluation. Each element observes its own boundaries and involves its own set of activities and processes (Manitoba Health Disaster Management 2002). The advantage of this model is that it provides a balance between preparedness and flexibility in order to respond fluidly to the specific needs of disasters. As this model provides the link between actions and events in disasters, such links can be tight or loose.

The third category of these models is cause models. The cause category is not based on the idea of defining stages in a disaster. This category suggests some underlying causes of disasters. The Crunch model is one of them which proposes a frame to understand the causes of a disaster (ADPC 2000; Cannon 2004; Bankoff 2001; Heijmans 2001; Marcus 2005). This model is based on the belief that there are some factors that affect the vulnerability to disasters. In this model, these factors are named as components at risk such as lives and properties of humans, environment and infrastructures. The progression of vulnerability of a community is revealed and the underlying causes that fail to satisfy the demands of the people are identified. The model then goes on to estimate the dynamic pressure and unsafe conditions.
The fourth category consists of combinatorial models in which the logical, integrated and cause models are combined to propose a model. The Cuny model is one of these models which is made by compilation of features of the other three categories (Cuny 1998).

Finally, the fifth category applies to other models in which no features of the other mentioned categories has been used. These models are miscellaneous and refer to a condition that the structure and template of the model is not located in any of the four mentioned categories. For example, Ibrahim, Fakharu'l-razi and Mustapha (2003b) proposed a model to show the pre-condition stages of technological disasters. Details of this model have been raised by Shaluf et al. (2003) and Ibrahim, Fakharu'l-razi and Aini (2003a). This model consists of eight phases: inception of error, accumulation of errors, warning, failure of correction, disaster impending stages, triggering events, emergency stage and disaster.

As this article does not have the capacity of a design and one by one explain models with their schematic views, their general characteristics, including name, reference, modeller, presentation year and conceptual elements of the model, are presented in Table 1. The result of the first step of thematic analysis approach is also presented in this table. According to this table, elements of each model are recognised as the primary themes of the study.

The second step of the study process is analysing the models. In this stage, we attempted to extract and classify themes of each model using thematic analysis. This method requires three stages. In the first stage, which is descriptive coding, existing elements in each model were extracted as code and then the basic themes that are the repetitive and distinguished features in the text were recognised. Then, in the stage of interpretive coding, basic themes were classified in three categories that are called organising themes. These categories are hazard assessment, risk management and management actions. The last stage is determination of the overarching theme which is formed from all the other mentioned themes (King \& Horrocks 2010).

\section{Hazard assessment themes}

Hazard assessment means a series of actions including planning and control in order to reduce the consequences of humans' harmful activities that can cause human casualties and social, 
economic and environmental damage. Considering the mentioned concept, among the enumerated models for disaster management, some models emphasise the existing factors and the concept of hazard assessment. These factors affect the crisis cycle and performance in different ways. In fact, the basis of good performance can be searched among these items and also the weak performance can be attributed to these factors. Therefore, it can be said that these models explain the reasons and are effective in recognising the reasons of current status and also designing the ideal status because there cannot be any planning or decision-making for development and improvement without identifying the contexts and triggers.

\section{Risk management themes}

The purpose of risk management is generally information assessment (collecting, classifying and analysis) of hazards in order to effectively plan and organise the needed resources for reconstruction and providing a balance in operational power of the city or the organisation after the disaster (Parker 1995). Risk management is, of course, a new approach that has found a good place in the field of crisis and has slowly overcome the traditional approach of crisis management, and in some cases is trying along with it to solve the problems and completing the progress of this subject.

\section{Management actions themes}

Some models have pointed to different stages that they should take continuously for disaster management. In the literature of disaster management, these models are called process-oriented models. Process themes of these models are in a logical sequence and order that separating or prioritising them in terms of frequency will demolish the spirit of the process and the order of stages. Therefore, by continuous comparison of models with each other, hazard assessment, risk management and management actions themes (components) were extracted in terms of frequency (Table 2).

\section{Thematic network}

One of the thematic analysis tools is drawing a thematic network that simplifies organising of the themes and its purpose is subject perceptions (Attride-Stirling 2001). Based on the basic and organising themes that were obtained from analysis of the models, a thematic network was developed and delineated using interpretive structural modelling (Figure 2). This network shows the connections across columns and between components.

\section{Models typology}

Differences and some variances among different models of disaster management have led to complications in this conceptual structure and theoretical chaos. Bailey (1994) claims that well-formed typology can be very effective in establishing discipline in a chaotic environment and in reducing complication.

Based on the thematic analysis of models, it can be concluded that disaster management models have three main themes;
TABLE 2: Identified themes in hazard assessment, risk management and management actions.

\begin{tabular}{lc}
\hline Component & Number of repetitions \\
\hline Hazard assessment & 7 \\
Exposure analysis & 7 \\
Hazard identification & 6 \\
Hazard forecast & 7 \\
Hazard analysis & 10 \\
Vulnerability assessment & 4 \\
Resource assessment & \\
Risk management & 6 \\
Risk context & 2 \\
Risk communication & 6 \\
Risk identification & 11 \\
Risk analysis & 6 \\
Risk evaluation & 14 \\
Risk treatment & 3 \\
Monitoring and revising the risk control plan & \\
Management actions & 13 \\
Prevention and warning & 14 \\
Mitigation & 17 \\
Preparedness & 21 \\
Response & 20 \\
Recovery (reconstruction and rehabilitation) & 10 \\
Learning and development &
\end{tabular}

these elements are the three organising themes (i.e. hazard assessment, risk management and management actions). Therefore, a comprehensive model of disaster management should include these themes, which is called the ideal type. Thus, inspired by Bailey's method in building typology, eight possible types can be recognised from the presence or the absence of each of these themes (Table 3). The most complete type includes all the features which Bailey addresses as the criterion type and the most incomplete one has none of the features. These two types that are placed at two ends of the spectrum are called polar types and other table cells are called middle types (Bailey 1994). These types act as conceptual containers that contain different instances (models).

Therefore, based on different combinations of the three organising themes, a complete typology was made that includes seven models. According to the presented typology, disaster management models can be classified in three categories: onedimensional models that include three types of typology table and only pay attention to one theme of comprehensive disaster management, two-dimensional models that form the other three types and have more abundance compared to the onedimensional models and three-dimensional models that occupy only one type, which is the ideal type.

After surveying the mentioned models, considering the necessity of studying the effective sub-components of disaster management in each identified organising theme, this section discusses sub-components in the ideal type. Table 4 shows the sub-components of three organising themes in the selected ideal models.

Reviewing the mentioned tables, it can be stated that each of the presented models have studied some components in which 


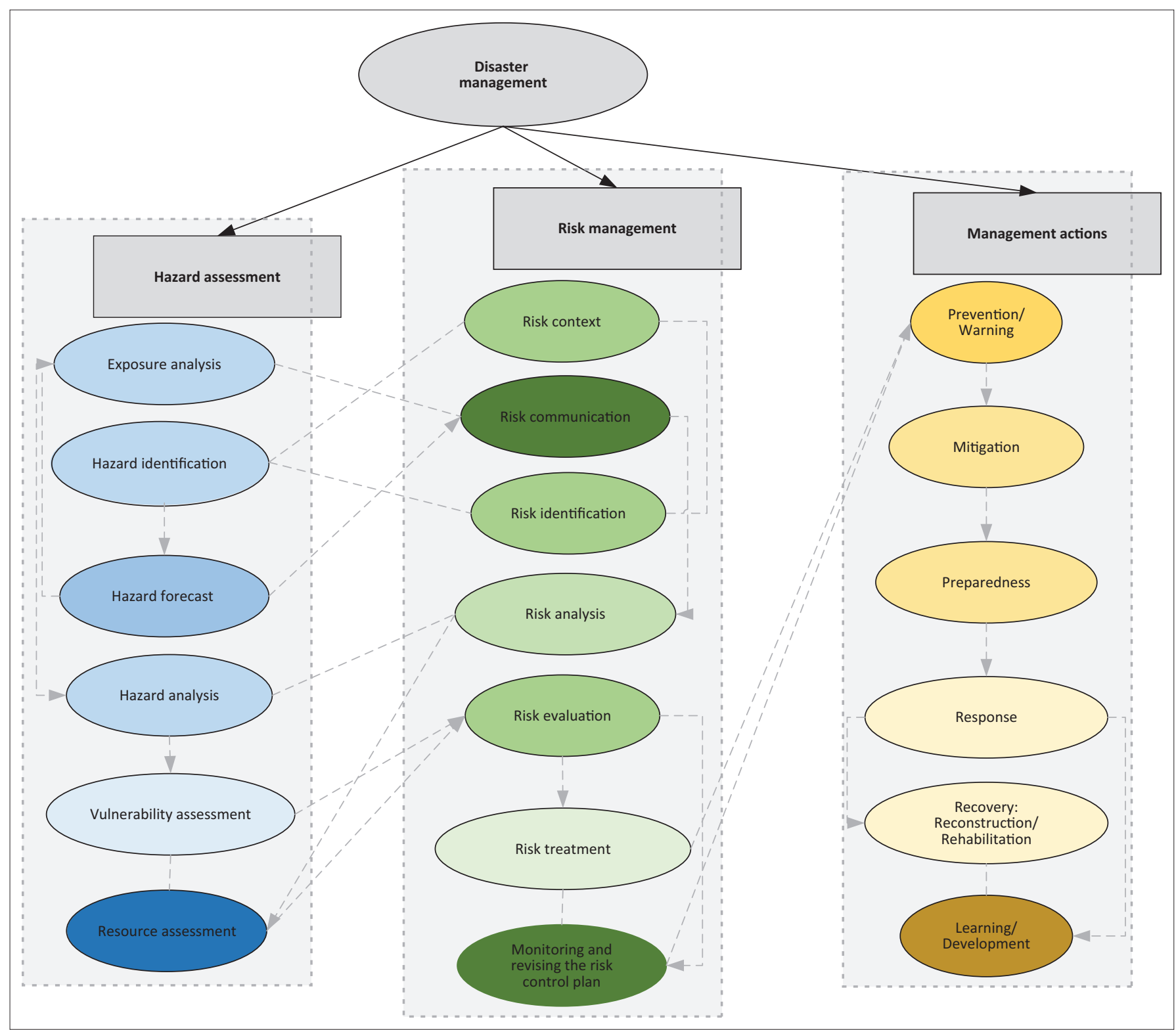

FIGURE 2: Disaster management thematic network.

TABLE 3: Typology of disaster management models (first phase).

\begin{tabular}{|c|c|c|c|c|c|}
\hline Hazard assessment & Risk management & Management actions & Status & Typologies & Models \\
\hline \multirow[t]{4}{*}{ Existence: 1} & Existence: 1 & Existence: 1 & $1-1-1$ & Ideal & $\begin{array}{l}\text { The two-part, Manitoba, Weichselgartner, wheel-shape, Cuny and monitoring } \\
\text { and evaluating model of disaster risk management models }\end{array}$ \\
\hline & & Absence: 0 & $1-1-0$ & Two-dimensional & $\begin{array}{l}\text { McConkey, Crunch, Pressure and Release (PAR), Fink's Comprehensive Audit, } \\
\text { Baas et al. and Fink models }\end{array}$ \\
\hline & Absence: 0 & Existence: 1 & $1-0-1$ & Two-dimensional & Ibrahim et al. model \\
\hline & & Absence: 0 & $1-0-0$ & One-dimensional & McEntire et al., Onion, Gonzalez Herrero and Pratt and Pagoda models \\
\hline \multirow[t]{4}{*}{ Absence: 0} & Existence: 1 & Existence: 1 & $0-1-1$ & Two-dimensional & $\begin{array}{l}\text { Mitroff, Moe and Pathranarakul, Australian Development Gateway, Institutional } \\
\text { model for collaborative disaster risk management and Saldana-Zorrilla models }\end{array}$ \\
\hline & & Absence: 0 & $0-1-0$ & One-dimensional & PDCA, Littlejohn, Statoil and Octopus models \\
\hline & Absence: 0 & Existence: 1 & $0-0-1$ & One-dimensional & $\begin{array}{l}\text { Traditional, Expand and contract, Kimberly, Tuscaloosa, Kelly, Lechat, Mitroff } \\
\text { and Pearson, Gupta, Iceberg, Zimmermann and Kull, Integrated system- } \\
\text { oriented and Contreras models }\end{array}$ \\
\hline & & Absence: 0 & $0-0-0$ & None & - \\
\hline
\end{tabular}

PDCA, Plan Do Check Act.

some of the effective components have been forgotten. Even in studies that have included almost all three organising themes in their models, they have ignored some sub-components of each theme. However, the comprehensive model should include all themes and the related sub-components.

\section{Results and discussion}

As it was mentioned, most of the models have studied some components, while some components have been forgotten. The traditional, Expand and contract, Kimberly, Tuscaloosa, 
TABLE 4: Typology of disaster management models (second phase).

\begin{tabular}{|c|c|c|c|c|c|c|c|}
\hline \multirow[t]{2}{*}{ Original themes } & \multirow[t]{2}{*}{ Components } & \multicolumn{5}{|c|}{ Selected models } & \multirow{2}{*}{$\begin{array}{l}\text { Monitoring and } \\
\text { evaluating model } \\
\text { of disaster risk } \\
\text { management }\end{array}$} \\
\hline & & $\begin{array}{l}\text { The two-part } \\
\text { model }\end{array}$ & $\begin{array}{l}\text { Manitoba } \\
\text { model }\end{array}$ & $\begin{array}{l}\text { Weichselgartner } \\
\text { model }\end{array}$ & $\begin{array}{l}\text { Wheel-shape } \\
\text { model }\end{array}$ & Cuny model & \\
\hline \multirow[t]{5}{*}{ Hazard assessment } & Exposure analysis & $\checkmark$ & - & $\checkmark$ & - & $\checkmark$ & - \\
\hline & Hazard identification & - & - & - & - & $\checkmark$ & - \\
\hline & Hazard forecast & $\checkmark$ & - & - & $\checkmark$ & $\checkmark$ & - \\
\hline & Hazard analysis & - & $\checkmark$ & $\checkmark$ & - & $\checkmark$ & - \\
\hline & Resource assessment & - & $\checkmark$ & - & $\checkmark$ & $\checkmark$ & - \\
\hline \multirow[t]{6}{*}{ Risk management } & Risk context & $\checkmark$ & - & - & - & - & - \\
\hline & Risk communication & - & - & - & - & $\checkmark$ & $\checkmark$ \\
\hline & Risk identification & $\checkmark$ & - & - & $\checkmark$ & $\checkmark$ & - \\
\hline & Risk analysis & - & $\checkmark$ & $\checkmark$ & - & $\checkmark$ & $\checkmark$ \\
\hline & Risk evaluation & $\checkmark$ & - & $\checkmark$ & - & $\checkmark$ & - \\
\hline & Risk treatment & $\checkmark$ & $\checkmark$ & $\checkmark$ & - & $\checkmark$ & - \\
\hline \multirow[t]{6}{*}{ Management actions } & Prevention and warning & $\checkmark$ & - & $\checkmark$ & $\checkmark$ & $\checkmark$ & - \\
\hline & Mitigation & - & $\checkmark$ & $\checkmark$ & - & $\checkmark$ & - \\
\hline & Preparedness & - & $\checkmark$ & $\checkmark$ & $\checkmark$ & $\checkmark$ & $\checkmark$ \\
\hline & Response & $\checkmark$ & - & $\checkmark$ & $\checkmark$ & $\checkmark$ & - \\
\hline & Recovery (reconstruction and rehabilitation) & $\checkmark$ & - & $\checkmark$ & $\checkmark$ & $\checkmark$ & - \\
\hline & Learning and development & - & - & - & $\checkmark$ & $\checkmark$ & - \\
\hline
\end{tabular}

$\checkmark$, The studied model has considered the respective component.

Kelly, Lechat, Mitroff and Pearson, Gupta, Iceberg, Zimmermann and Kull models are examples of onedimensional type that only paid attention to the managing dimension (factors and indicators). These models can only be used in studying the process of management. Processoriented models mostly have a logical order and consecutive stages so that imperfect implementation or neglect of each stage will lead the whole process into problems.

Another type of one-dimensional model includes the Plan Do Check Act (PDCA), Littlejohn, Statoil and Octopus models, which only considered risk management. The unique feature of this model is the development and sequence in risk mitigation by focusing on the pre-disaster stage.

The third type of one-dimensional models includes the McEntire et al., Onion, Gonzalez Herrero and Pratt and Pagoda models that pay attention to hazard assessment.

In the two-dimensional type that includes themes such as hazard assessment and management actions, the only model is the Ibrahim et al. model. Indeed, this model consists of two parts, one within the other. The first stage from the eight-stage pattern of Ibrahim et al. is determination of consequences that will end eventually with occurrence of an emergency and disaster condition. This model is proposed to show the precondition stages of technological disasters. In this study, the eight-stage model has been combined with a three-stage pattern of the study and is mentioned as a two-dimensional model.

The two-dimensional type that includes the themes of risk management and management actions includes models such as the Mitroff, Moe and Pathranarakul and Australian Development Gateway models. These models can be called operational management models because they only pay attention to process and the way of management without considering hazard assessment. For example, in the Mitroff model, the operational aspect is considered and its structure is proposed through risk management. The special feature of this model is that it is a proactive model that pays much attention to the learning element.

In the McConkey, Crunch, Pressure and Release (PAR), Fink's Comprehensive Audit, Baas et al. and Fink models, there has been a great deal of attention to hazard assessment and risk management. In these models, the only missing link among the three main study components is the process or management actions. So, these models are also included in the two-dimensional models category.

Finally, the seventh type, which is called the ideal (criterion) type, includes the three-dimensional models. These models can be called comprehensive models of disaster management because they include all three organising themes. Although the two-part model of crisis management is a processing and operational model in an overview by reviewing factors such as prevention, response and reconstruction, but in the first stage of process that is recognising the hazard with an emphasis on exposure analysis, it is a multidimensional model and has studied risk management dimensions (i.e. risk context, identify risk, evaluate and treat risk) at the end.

The Manitoba model initially proposes a three-stage model that constantly tries to aggregate the components of comprehensive disaster management. By reviewing the three organising themes, this model tries to propose an appropriate model. The feature and advantage of this model is providing balance between preparedness and flexibility (resilience) in order to respond to the disasters, special needs. 
The main purpose of the Weichselgartner model is assessment of probable damages and planning for future actions to reduce these damages. This model also tries to propose a comprehensive model by studying components that are shown in Table 4.

The wheel-shape model is also considered a processingoperational model, but it can be considered as one of the three options of models by reviewing components such as resource assessment in the field of hazard assessment and risk identification in the field of risk management.

But among all the mentioned models in this study, only the Cuny model has reviewed the components more comprehensively and has covered most of the study's desired components, except risk context and monitoring in the field of risk management. Cuny has proposed a cycle for disaster management that considers all the required management and executive actions that need to be carried out in the course of a disaster. In this cycle, there are several stages and sub-stages so that deliniating boundaries is not possible among them. Besides, sometimes, according to the disaster type, transposition of these stages change and sometimes, a number of these stages do not exist among some models. In other words, a combination of logical, integrated and cause models has been used in this model's structure.
Nevertheless, it becomes clear that some scientists have looked at disaster management one-dimensionally; even in some two-dimensional models, one dimension has more advantage. While the proposed typology in this study indicated that based on the ideal type, the comprehensive model should include three above-mentioned themes. Considering this point and by studying the mentioned models, the proposed conceptual model of this study is presented in Figure 3. This model and three stages of process and concepts within them, relations and their transposition are the results of thematic analysis of the literature review.

Based on this conceptual model for developing a comprehensive model of disaster management, initially three main questions should be answered:

- What is the role of environmental factors in this model?

- How are the elements that received the least attention in the previous models covered in the proposed model?

- How is the position of feedback exerted and applied in this study?

As disasters' dimensions are different in various places, each organisation should determine their performance level and dimensions in accordance with the requirements and based on their vision, mission, goals and strategies and then try to design the indicators. So, every organisation or part should act

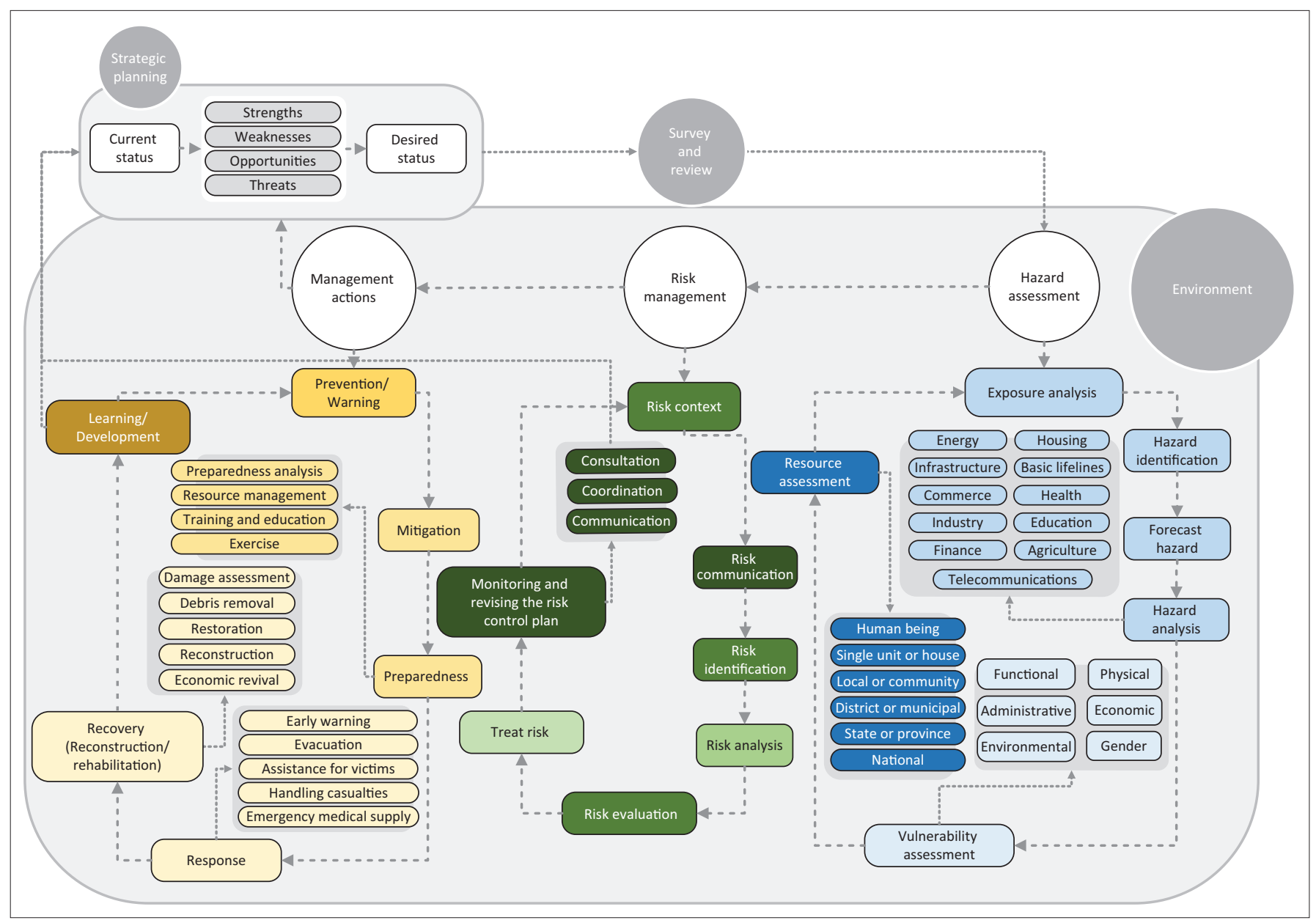

FIGURE 3: Comprehensive conceptual model of disaster management. 
at various levels in disaster management considering existing resources and try to reduce the consequences of disaster in different spaces with the consideration of vulnerability factors such as social and economic factors. Therefore, based on the performed study and the above-mentioned model, the environmental factor is an inseparable factor in different parts of the model and it should be checked on all three levels.

Various models have proposed an approach for disaster management, so their role is significant in previous disasters. Now that special attention of each model to a special context has prevented them from paying attention to all effective factors in management. Based on this point, in the current study, we attempted to complete the previous models and, considering the colour spectrum, proposed in the model. The issues that have not been considered in the previous models are shown with dark surfaces.

In the proposed model, feedback's position is determined using measures such as consultation, coordination and communication in order to complete the previous models. In most proposed models so far, this point was forgotten as a missing link and few models have considered it as an effective option in the field of disaster.

The final point about the proposed model is that hazard assessment is a prerequisite element for risk management, not a part of it. If vision, mission, objectives and strategies have been pointed out in the model's first stage, the intention is not just writing about them but to study and contemplate them in order to determine effective dimensions and factors of comprehensive disaster management. Therefore, in disaster management, goals and strategies that are written in hazard assessment, risk management and management actions are used to determine the key factors and dimensions and performance measures.

\section{Conclusion}

In this study, a comprehensive conceptual model for disaster management was presented. To overcome the complications and conceptual inconsistencies among the models, thematic analysis, classification and typology were used. In this regard, first, the models of disaster management were collected. In the next stage, the themes of each model were extracted and categorised using thematic analysis in three phases. In the first phase, available elements in each model were extracted as code and the basic themes were recognised. Then, in the phase of interpretive coding, basic themes were classified in three categories that are called organising themes. Finally, in the last phase, a global or overarching theme that consists of all the other mentioned themes was determined. Basic themes which were obtained during interpretive coding are the themes of hazard assessment, risk management and management actions. Based on thematic analysis of the models, it can be concluded that disaster management has three main elements, namely the three organising themes. Therefore, the comprehensive model of disaster management should include these three themes and their sub-basic themes that is called the ideal type that includes all the features and is also known as the criterion type. Results showed that some scientists have looked at disaster management onedimensionally (one theme). Even in two-dimensional models, one dimension has advantage over the other one. Special attention of each model to a special context has prevented them from paying attention to all the effective factors in efficient and comprehensive management and the role of environmental factors is ignored in most of the models. However, the proposed typology in this study showed that, considering the ideal type, the comprehensive model should include all the three mentioned themes.

Finally, considering this point, the suggested conceptual model of this study was proposed, using the concepts of strategic and comprehensive management. According to the proposed conceptual model, the strategic plan of disaster management should be performed under a comprehensive management, considering all the aspects which are connected with disasters and using the comprehensive management pattern. Also, in the proposed model, feedback's position was determined using measures such as consultation, coordination and communication in order to complete the previous proposed models. In most proposed models so far, this point was forgotten as a missing link and few models have considered it as an effective option in the field of disaster. Finally, the proposed model may be applied in the various phases of disasters in different places.

\section{Acknowledgements}

This manuscript is derived from the $\mathrm{PhD}$ thesis of the first author entitled 'Analysing and presenting the conceptual planning model in Natural Disaster Management' under the supervision of Dr Esmail Salehi and Dr Babak Omidvar.

\section{Competing interests}

The authors declare that they have no financial or personal relationships which may have inappropriately influenced them in writing this article.

\section{Authors' contributions}

M.N. wrote the manuscript with support from E.S. and B.O. as the supervisors of the research. M.N., E.S. and B.O. discussed the results and contributed to the final manuscript.

\section{References}

Aguayo, R., 1991, Dr. Deming: The American who taught the Japanese about quality, Touchstone Publishers, Fireside.

Alexander, D., 1997, 'The study of natural disasters, 1977-1997: Some reflections on a changing field of knowledge', Disasters 21(4), 284-304. https://doi.org/10.1111/ 1467-7717.00064

Alexander, D.E., 2016, 'The game changes: Disaster prevention and management after a quarter of a century', Disaster Prevention and Management 25(1), 2-10. https:// doi.org/10.1108/DPM-11-2015-0262

Asgary, A., 2006, 'Theorizing disaster and emergency management', in C. Raj Kumar \& D.K. Srivastava (eds.), Tsunami and disaster management: Law and governance, Thomson, Hong Kong, p. 42.

Asghar, S., Alahakoon, D. \& Churilov, L., 2006, 'A comprehensive conceptual model for disaster management', Journal of Humanitarian Assistance, viewed 10 February 2017, from https://sites.tufts.edu/jha/articles/page/8 
Asian Disaster Preparedness Centre (ADPC), 2000, Community Based Disaster Management (CBDM): Trainer's guide, Module 4: Disaster management, Asian Management (CBDM): Trainer's guide, Module 4:
Disaster Preparedness Centre, Bangkok, Thailand.

Attride-Stirling, J., 2001, 'Thematic networks: An analytic tool for qualitative research', Qualitative Research 1(3), 385-405. https://doi.org/10.1177/146879410100100307

Australian Development Gateway, 2008, The disaster risk management cycle, viewed 20 February 2017, from http://www.developmentgateway.com.au/jahia/webdav/ site/adg/shared/DRMC_Torqaid.pdf

Baas, S., Ramasamy, S., DePryck, J.D. \& Battista, F., 2008, Disaster risk management systems analysis, A guide book, FAO, Rome.

Bailey, K.D., 1994, Typologies and taxonomies: An introduction to classification techniques, Sage University papers: Quantitative applications in the socia sciences, No. 07-102, Sage, Thousand Oaks, CA.

Bankoff, G., 2001, 'Rendering the world unsafe: Vulnerability as western discourse', Disasters 25(1), 19-35. https://doi.org/10.1111/1467-7717.00159

Bendito, A. \& Barrios, E., 2016, 'Convergent agency: Encouraging transdisciplinary approaches for effective climate change adaptation and disaster risk reduction', International Journal of Disaster Risk Science 7, 430-435.

Blaikie, P., Mainka, S. \& McNeely, J., 2005, The Indian Ocean tsunami: Reducing risk and vulnerability of future natural disasters and loss of ecosystem services, Information Paper, The World Conservation Union (IUCN), Gland, Switzerland.

BPDMP, 2013, Badakhshan provincial disaster management plan, Provincial Disaster Management Committee, National Disaster Management Authority, Islamic Republic of Afghanistan, Kabul.

Cannon, T., 2004, 'At risk: Natural hazards, people's vulnerability and disasters', paper presented at CENAT Conference, Ticino, Switzerland, 28 November-03 December.

Contreras, D., 2016, 'Fuzzy boundaries between post-disaster phases: The case of L'Aquila, Italy', International Journal of Disaster Risk Science 7, 277-292.

Cuny, F., 1998, Principles of management: Introduction to disaster management, University of Wisconsin-Madison Press, Madison, WI.

Doty, D.H. \& Glick, H.W., 1994, 'Typologies as a unique form of theory building: Toward improved understanding and modelling', The Academy of Management Review 19(2), 230-251.

DPLG-2, 1998, 'Green paper on disaster management: Chapter 2 and 3', Department of Provincial and Local Government, viewed 15 January 2017, from http://www. local.gov.za/DCD/policydocs/gpdm/gpdm2-3.html

Dutta, V., 2012, 'War on the dream, how land use dynamics and peri-urban growth characteristics of a sprawling city devour the master plan and urban suitability, a fuzzy multi criteria decision making approach', in 13th Global Development Conference 'Urbanization and Development: Delving Deeper into the Nexus', Budapest, Hungary, June 16-18, 2012, pp. 1-44.

Fink, S., 1986, Crisis management: Planning for the inevitable, American Management Association, New York.

Given, L.M., 2008, The Sage encyclopaedia of qualitative research methods, Sage, Thousand Oaks, CA.

González-Herrero, A. \& Pratt, C.B., 1996, 'An integrated symmetrical model for crisiscommunication management', Public Relations Research 8(2), 79-105. https:// doi.org/10.1207/s1532754xjprr0802 01

Gupta, M., 2010, Afghanistan national disaster management plan, UNDP, Kabul.

Heinreich, H.W., 1941, Industrial accident prevention: A scientific approach, McGrawHill, New York.

Heijmans, A., 2001, Vulnerability: A matter of perception, Disaster Management Working Paper 4/2001, Benfield Greig Hazard Research Centre, University College of London.

Hosseini, H. \& Jedi, S.M., 2006, Crisis management from the public security perspective, Amoozesh-e-Naja Publishers, Tehran, Iran.

Ibrahim, M.S., Fakharu'I-razi, A. \& Aini, M.S., 2003a, 'A review of disaster and crisis', Disaster Prevention Management 12(1), 24-32. https://doi.org/10.1108/ 09653560310463829

Ibrahim, M.S., Fakharu'I-razi, A. \& Mustapha, S., 2003b, 'Technological disaster's criteria and models', Disaster Prevention Management 12(4), 305-311. https:// doi.org/10.1108/09653560310493114

Jha, K., Miner, W. \& Geddes, S., 2012, Building urban resilience: Principles, tools, and practice, The World Bank, Washington, DC.

Kelly, C., 1998, 'Simplifying disasters: Developing a model for complex nonlinear events', paper presented at International Conference on Disaster Management: Crisis and Opportunity: Hazard Management and Disaster Preparedness in Australasia and the Pacific Region, Cairns, Queensland, Australia, November 1-4.

Kimberly, A., 2003, 'Disaster preparedness in Virginia Hospital Centre-Arlington after Sept 11, 2001', Disaster Management Response 1(3), 80-86. https://doi. org/10.1016/S1540-2487(03)00048-8

King, N. \& Horrocks, C., 2010, Interviews in qualitative research, Sage, Thousand Oaks, CA

Kraas, F., 2008, 'Megacities as global risk areas', in J.M. Marzluff, W. Endlicher G. Bradley, U. Simon, E. Shulenberger, M. Alberti, et al. (eds.), Urban ecology: An international perspective on the interaction between humans and nature, pp. 583-596, Springer, New York, viewed 13 October 2016, from http://www. springer.com

Lechat, M.F., 1990, 'The international decade for natural disaster reduction background and objectives', Disasters 14(1), 1-6. https://doi.org/10.1111/j.1467-7717.1990. tb00967.x
León, J. \& March, A., 2014, 'Urban morphology as a tool for supporting tsunami rapid resilience: A case study of Talcahuano, Chile', Habitat International 43, 250-262. https://doi.org/10.1016/j.habitatint.2014.04.006

Littlejohn, R.F., 1983, Crisis management - A team approach, American Management Associations, New York.

Manitoba Health Disaster Management, 2002, Disaster management model for the health sector: Guideline for program development, Version 1, Government of Manitoba, Manitoba, Canada.

Marcus, O., 2005, 'A conceptual framework for risk reduction', paper presented at World Conference of Disaster Reduction, January 18-22, 2005, Kobe, Hyogo, Japan.

McConkey, D., 1987, 'Planning for uncertainty', Business Horizons 30, 40-45. https:// doi.org/10.1016/0007-6813(87)90021-8

McEntire, D., Crocker, C.G. \& Peters, E., 2010, 'Addressing vulnerability through an integrated approach', Disaster Resilience in the Built Environment 1(1), 50-64. https://doi.org/10.1108/17595901011026472

Meshkati, N. \& Tabibzadeh, M., 2016, 'An integrated system-oriented model for the interoperability of multiple emergency response agencies in large-scale disasters: Implications for the Persian Gulf', International Journal of Disaster Risk Science 7, 227-244.

Mileti, D., 1999. Disasters by design: A reassessment of natural hazards in the United States, Joseph Henry Press, Washington, DC.

Mills, A.J., Durepos, G. \& Wiebe, E., 2010, Encyclopedia of case study research, Sage, Thousand Oaks, CA.

Mitroff, I., 2000, Managing crises before they happen: What every executive needs to know about crisis management, AMACOM Publishers, New York.

Mitroff, I. \& Pearson, C.M., 1993, Crisis management: A diagnostic guide for improving your organization's crisis-preparedness, Jossey Bass Business and Management Series, Wiley Publishers, San Francisco, CA.

Mitroff, I., Shrivastava, P. \& Udwadia, F.E., 1978, 'Effective crisis management' Academy of Management Executive Journal 1(4), 283-292. https://doi. Academy of Management Exe
org/10.5465/AME.1987.4275639

Moe, T.L. \& Pathranarakul, P., 2006, 'An integrated approach to natural disaster management', Disaster Prevention Management 15(3), 396-413. https://doi. org/10.1108/09653560610669882

Mohapatra, R., 2009, 'Community based planning in post-disaster reconstruction: A case study of tsunami affected fishing communities in Tamil Nadu Coast of India', PhD thesis, University of Waterloo.

Nojavan, M., Salehi, E. \& Omidvar, B., 2018, 'Conceptual change of disaster management models: A thematic analysis', Jàmbá: Journal of Disaster Risk Studies 10(1), a451. https://doi.org/10.4102/jamba.v10i1.451, for more information.

Okada, N., 2004, 'Urban diagnosis and integrated disaster risk management', Natural Disaster Science 26(2), 49-54.

Parker, G., 1995, Dimension of risk management: Definition and implication for financial service: Risk management problems and solution, McGraw Hill, New York.

Penrose, J.M., 2000, 'The role of perception in crisis planning', Public Relations Review 26(2), 155-171. https://doi.org/10.1016/S0363-8111(00)00038-2

Quarantelli, E.L., 1994, Twenty criteria for evaluating disaster planning and managing and their applicability in developing societies, Preliminary Paper \#199, Disaster Research Center, University of Delaware, Delaware, Newarc, p. 49.

Rich, P., 1992, 'The organizational taxonomy: Definition and design', The Academy of Management Review 17(4), 758-781.

Rowshandel Arbatani, T., Purezzat, A. \& Qolipoor, A., 2008, 'Presenting a comprehensive pattern of crisis management with the viewpoint of security', Danesh-e-Entezam 10(2), 60-84.

Saldana-Zorrilla, S.O., 2015, 'Assessment of disaster risk management in Mexico' Disaster Prevention and Management 24(2), 230-248. https://doi.org/10.1108/ DPM-11-2013-0201

Scott, Z., Wooster, K., Few, R., Thomson, A. \& Tarazona, M., 2016, 'Monitoring and evaluating disaster risk management capacity', Disaster Prevention and Management 25(3), 412-422. https://doi.org/10.1108/DPM-01-2016-0002

Shaluf, I., Ahmadun, F., Rashid, S. \& Saari, M., 2003, 'Fire explosion at mutual major hazard installations: Review of a case history', Loss Prevention in Process Industries 16(2), 149-155. https://doi.org/10.1016/S0950-4230(02)00094-3

Shi, P., Xu, W., Ye, T., He, C., Wang, J. \& Li, N., 2011, 'Developing disaster risk science, discussion on the disaster reduction implementation science', Natural Disaster Science 32(2), 79-88. https://doi.org/10.2328/jnds.32.79

Statoil, 2013, The In Amenas attack: Report of the investigation into the terrorist attack on In Amenas, prepared for Statoil ASA's board of directors, Statoil ASA Norway, Stavanger.

Tau, M., Niekerk, D. \& Becker, P., 2016, 'An institutional model for collaborative disaster risk management in the Southern African Development Community (SADC) region', International Journal of Disaster Risk Science 7, 343-352. https:// doi.org/10.1007/s13753-016-0110-9

Tuscaloosa, E.M.A., 2003, Tuscaloosa county emergency management cycle, viewed 18 September 2016, from www.tuscoema.org/cycle.html

Van der Waldt, G., 2013, 'Disaster risk management: Disciplinary status and prospects for a unifying theory', Jàmbá: Journal of Disaster Risk Studies 5(2), Art. \#76, 1-11. https://doi.org/10.4102/jamba.v5i2.76

Weichselgartner, J., 2001, 'Disaster mitigation: The concept of vulnerability revisited' Disaster Prevention Management 10(2), 85-94. https://doi.org/10.1108/ 09653560110388609

Zimmermann, M. \& Stössel, F., 2011, Disaster risk reduction in international cooperation: Switzerland's contribution to the protection of lives and livelihoods, Swiss Agency for Development and Cooperation, Berne, Switzerland. 